\title{
PSYCHOLOGY
}

\section{МЕХАНІЗМИ ПСИХОЛОГІЧНОГО ЗАХИСТУ ТА ЇХ ВЗАЕМОЗВ'ЯЗОК З ГЕНДЕРНОЮ ІДЕНТИЧНІСТЮ У ЮНАЦЬКОМУ ВІЦІ}

\author{
Кокоріна Ю. С., к.психол.н., доцент, дочент кафедри психології \\ Соколова В. Г., магістр кафедри психології
}

Украйна, м. Одеса, Одеський наиіональний медичний університет

DOI: https://doi.org/ 10.31435/rsglobal_ws/31102018/6206

\section{ARTICLE INFO}

Received: 12 August 2018

Accepted: 25 October 2018

Published: 31 October 2018

\section{KEYWORDS}

psychological defense mechanisms, gender identity, feminine gender, masculinity, androgyny.

\begin{abstract}
The article the features of the manifestations of the defense mechanisms of the psyche and their relation to gender identity in adolescence were considered. We have examined that in the manifestation of mechanisms of psychological defense there is a clear gender differentiation. It was found that the psychological defense mechanisms that are typical for men positively correlate with the defense mechanisms that are specific to feminine gender. Consequently, we can assume that men who are at socially-cultural, namely at the gender level, show more women's personality features, which appear unconsciously, as indicated by mechanisms of psychological defense, are use conditional women's strategies.
\end{abstract}

Citation: Кокоріна Ю. С., Соколова В. Г. (2018) Mekhanizmy Psykholohichnoho Zakhystu ta Yikh Vzaiemozviazok z Hendernoiu Identychnistiu u Yunatskomu Vitsi. World Science. 10(38), Vol.2. doi: 10.31435/rsglobal_ws/31102018/6206

Copyright: (C) 2018 Кокоріна Ю. С., Соколова В. Г. This is an open-access article distributed under the terms of the Creative Commons Attribution License (CC BY). The use, distribution or reproduction in other forums is permitted, provided the original author(s) or licensor are credited and that the original publication in this journal is cited, in accordance with accepted academic practice. No use, distribution or reproduction is permitted which does not comply with these terms.

Вступ. Розділ суспільства на дві статі $є$ фундаментальним соціально-біологічним фактом, з яким пов'язані численні проблеми життєдіяльності особистості. У 50-х роках XX століття ця проблема стала предметом уваги самих різних наук і отримала оформлення в гендерному підході до диференціації статей. Міждисциплінарний характер гендерних досліджень відражає складні взаємозв'язки біологічних, соціальних, культурних, психологічних факторів, що лежать в основі регуляції поведінки.

Незважаючи на зовнішню відкритість даної проблеми, вона має значний внутрішній шар, що охоплює багато психологічних механізмів гармонійного, адаптивного або дисгармонійного, дезадаптивного розвитку людини в біологічно заданої статевої ролі.

Специфіка гендерних досліджень, як відзначають в сучасних оглядах, полягає в складності виділення жорстко зафіксованих закономірностей в силу домінуючого впливу соціокультурних детермінант на моделі статеворольової поведінки. Це не виключає наявності загальних тенденцій в психології гендерної поведінки, але підкреслює залежність захисних механізмів психіки не тільки від біологічної статі, але в значній мірі від змін культурного контексту становлення особистості.

Отже, з метою вивчення гендерних проблем психології особистості було обрано аспект, якій пов'язан з вивченням взаємозв'язку гендерної ідентичності і захисних механізмів психіки в юнацькому віці.

Результати дослідження. У ряді робіт, зокрема, В.С. Агєєва, С. Бем, В.С. Кагана, I.C. Кона, I.C. Клецина та ін., науковцями було зроблено акцент на те, що на певному етапі 
розвитку особистості гендерні особливості істотно впливають на іiі подальший соціальнопсихологічний розвиток, багато в чому визначаючи життєву позицію, емоційну спрямованість, вільний вибір індивідуального життєвого шляху, зміст і структуру мотиваційно-потребової сфери, а в кінцевому рахунку, рівень самосвідомості і самовизначення. При цьому більшість дослідників сходяться в тому, що ключовим, певною мірою критичним віковим етапом соціально-психологічного розвитку індивіда в плані формування як гендерної ідентичності, так і особистісного самовизначення $є$ юнацький вік. Саме в цьому віці (якщо умовно назвати юнацький вік студентським) суб'єкт знаходиться на стадії професійного самовизначення, порівняно зі школярами у них збільшуються інформаційне навантаження, нерівномірно i аритмічно розподілений робочий час, ускладнюються міжособистісні відносини, а у індивідів які прибули з віддалених районів, виникають проблеми пов’язані 3 віддаленістю від сім’ї та зміною місця проживання. Усі ці та багато інших факторів, які спричиняють труднощі у студентському житті, можуть стати причиною стану емоційної напруженості.

Адаптація до нових умов, які обумовлені початком навчання у ВНЗ пов'язана 3 тим, як особистість може впоратись зі зняттям емоційного напруження: у багатьох випадках подолання важкого емоційного стану здійснюється за допомогою механізмів психологічного захисту.

Психологічний захисний механізм як неусвідомлюване психічне явище визначає особливості сприйняття, ставлення та поведінки людини в різних життєвих ситуаціях. Це вказує на те, що особливості механізмів психологічного захисту мають великий вплив на всі сфери життя студента, а, оскільки провідна діяльність студентів навчально-професійна, вивчення прояву цих механізмів актуально і важливо, тому що у студентські роки формується особистість майбутнього фахівця i від якості засвоєння їм знань залежить рівень професіоналізму.

Психологічний захист сьогодні визнається і описується у всіх теоріях особистості, в різних підходах до людини. I, хоча типології захисних механізмів відрізняються, в цілому зберігається визначення психологічного захисту, запропоноване 3. Фрейдом. Тому для методологічного обгрунтування дослідження була обрана психодинамічна позиція погляду на механізми психологічного захисту, представлена у роботах 3. Фрейда, А. Фрейд, Л. Хьелла і Д. Зіглера та інших представників психоаналітичного напрямку. Саме 3. Фрейду належить першочергова роль у вивченні психологічного захисту . Їм була виділена дуже важлива сторона даної проблеми, а саме - психологічний захист - це природна особливість будь-якої людини, як здорової, так і хворої, який пов’язаний з тими прийомами, які «Я» використовує в конфлікті і які можуть призвести до неврозу [7].

Складність вивчення механізмів психологічного захисту - це складність самого об'єкта дослідження, у зв'язку з чим дослідникам доводиться керуватися принципом редукції. Захисні процеси суто індивідуальні, різноманітні і погано піддаються рефлексії. Крім того, спостереження за результатом дії механізмів психологічного захисту ускладнюються тим, що реальні стимули і реакції можуть бути відокремлені один від одного, в часі і просторі.

Наступною категорією яку ми досліджували у студентської молоді був гендер. Психоаналітична позиція, розглядає проблему статі і сексуальності як центральну для своєї теорії, заклавши основу для розуміння гендеру та гендерної ідентичності, ще до появи самих понять. Гендерна ідентичність, 3 психоаналітичної точки зору, формується у наслідку ідентифікації з одним з батьків і сексуальних імпульсів до іншого, іншими словами, перехід едіпової ситуації в ідентифікацію з батьком або матері залежить від відносної сили задатків того чи іншого пола. Це один спосіб, яким бісексуальність втручається у долю едіпова комплексу [8].

Існує кілька наукових підходів, що по різному інтерпретують феномен гендерних відносин. На сучасному етапі розвитку психологічної науки гендер - це соціально-культурний конструкт статі, який являє собою складний набір якостей і характеристик чоловічої і жіночої поведінки, спосіб життя, спосіб мислення, норм, цінностей і т.П. На відміну від біологічної статі, яка представляє собою набір генетичних, анатомічних i фізіологічних особливостей гендер будується в контексті соціальної культури в певний історичний період, і тому він змінюється в часі і просторі. Отже, гендер - продукт соціалізації, в той час як стать - результат еволюції .

Значний вклад у формування сучасного уявлення про гендер належить С. Бем, тому у нашому досліджені ми дотримуємося наведених нижче, запропонованих нею, термінів: 
Маскулінність - це риси, які властиві переважно чоловікам, традиційно є такі, як незалежність, впевненість в собі, домінування, агресивність, схильність до ризику, незалежність, почуття власної гідності та інші [1].

Фемінність - це риси, які властиві жіночій половині суспільства, традиційно розглядаються як гнучкість, м'якість, чутливість, сором'язливість, ніжність, теплота, здатність до співчуття, співпереживання та інші [1].

Андрогінія - це риси, які об'єднують у особі як чоловічі, так і жіночі властивості. Передбачається, що у андрогенів ці функції представлені в гармонії і взаємодоповнюваності [1].

Отже, для проведення дослідження з метою вивчення взаємозв'язку гендерної ідентичності і захисних механізмів психіки в юнацькому віці нами було використовувано методику «Статеворольовий опитувальник», яка була запропонована С. Бем для діагностики психологічної статі і визначає ступінь андрогінії, маскулінності і фемінності особистості [1]. А також методика, яку ми обрали, для діагностики механізмів психологічного захисту - «Індекс життєвого стилю», збудована на основі теоретичних досліджень Г. Келлермана, Р. Плутчика і Х. Р. Конте [10].

У досліджені приймали участь 52 особи, які у більшості $є$ студентами вищих навчальних закладів (ВН3). Серед них 26 дівчат і 26 юнаків, віком від 15 до 21 року. Дослідження проводилося на базі Одеського Національного Медичного Університету та Національного Університету (Одеська Морська Академія).

На підставі проведеного аналізу, ми можемо зробити висновки що, у прояві механізмів психологічного захисту існує виразна гендерна диференціація. Головною особливістю отриманих результатів можна вважати типовість застосування деяких захисних механізмів для жіночої і чоловічої статі, що можна побачити на діаграмі (рис. 1.).

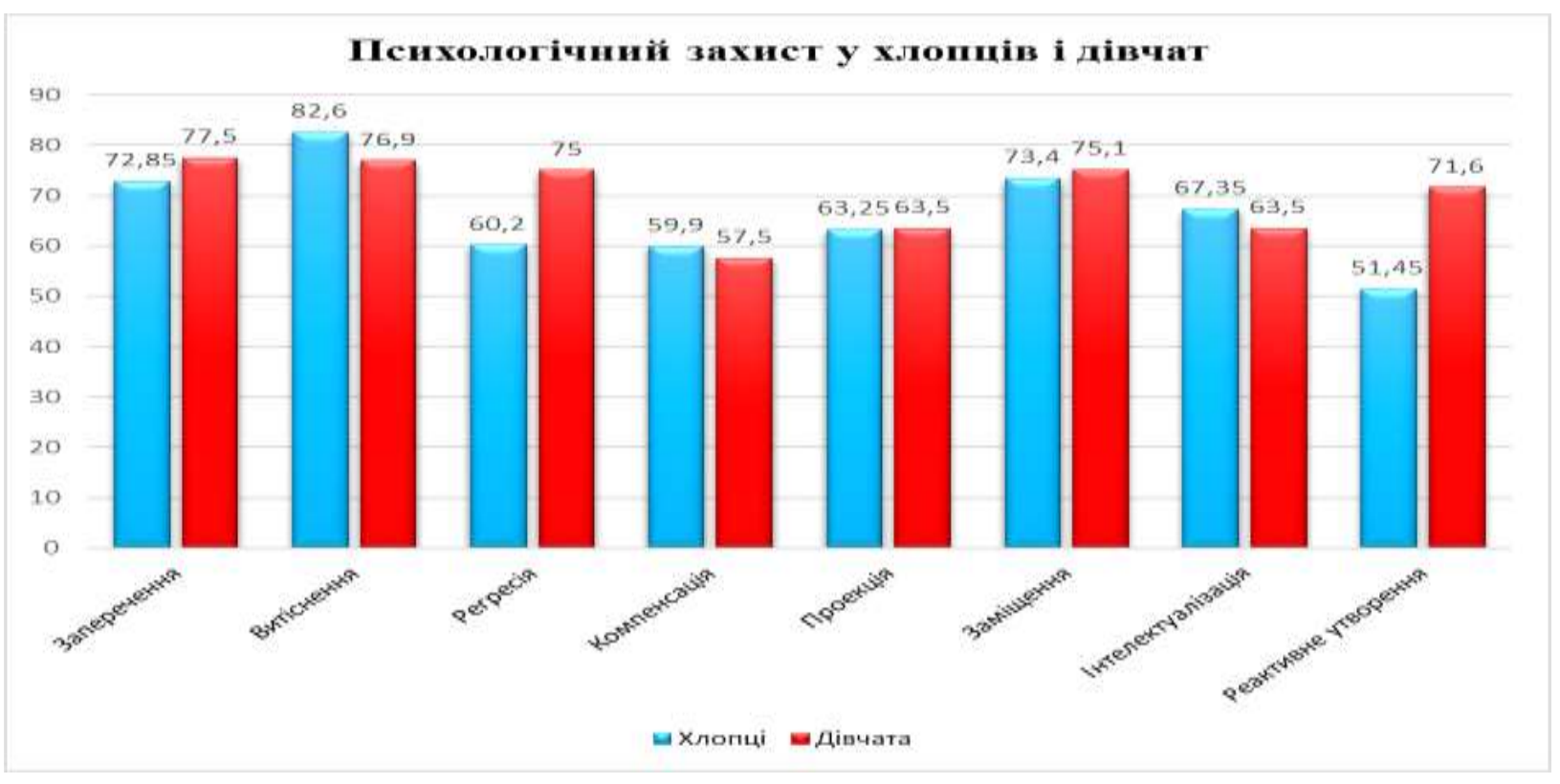

Рис.1. Психологічний захист у хлопцуів і дівчат

Як видно із діаграми, для представників жіночої статі типовими є такі механізми психологічного захисту як: «регресія» (75\%), та «реактивне утворення» $(71,6 \%)$. Такі результати можуть буди пов'язані з впливом соціально-культурних стереотипів щодо виховання дівчат. Відомо, що 3 самого раннього дитинства людина, особливо дівчинка, стикається 3 забороною на прояв агресивних емоцій по відношенню до інших людей, тому вони навчаються приховувати осуджені суспільством емоції, замінюючи їх на протилежні, проявляючи тим самим «реактивне утворення», як підміну негативного почуттів на соціально схвалювані. Крім того, в культурі і суспільстві деякі аспекти проявів регресивної або «інфантильної» поведінки (плаксивість, сенситивність, залежність, демонстративність і т.п.) відповідає фемінним статеворольовим стереотипам і стандартам, що абсолютно неприйнятно для чоловіків, так як не відповідає образу типової маскулінності. Можливо, саме тому для хлопчиків статевотиповим є такий захисний механізм, як «витіснення» $(82,6 \%)$, який допомагає вимикати зі сфери свідомості неприйнятні емоції і спонукання. Характерним для чоловічої статі є також механізм «інтелектуалізація» (67,3\%), який дає ілюзію когнітивного контролю над ситуацією, з проявом ознак зовнішньої самодостатності і незалежності. 
Проаналізувавши експериментально отримані данні у досліджені, ми можемо говорити про те, що не залежно від біологічної статі, механізми психологічного захисту більше всього корелюють 3 результатами індивідів яким властиві риси андрогінного гендеру (коефіцієнт кореляції 3 чоловічою статтю склав P>0,9, 3 жіночою $\mathrm{P}>0,8)$. Ми пов’язуємо це з тим, що переважна більшості індивідів, які приймали участь у нашому дослідженні, як показує тестування, є носіями рис характеру властивих і для чоловічої, і для жіночої статі. У представників андрогінного гендеру майже не виявляється (порівняно 3 фемінним i маскулінним гендером) окремих особливостей прояву механізмів психологічного захисту, тобто індивіди які мають риси характеру, які властиві як для чоловіків, так i для жінок, мають і механізми психологічного захисту без прояву статевої диференціації, що можна побачити на діаграмах наведених нижче (рис. 2., рис. 3.).

Розглядаючи фемінний гендер, ми помічаємо, що механізми психологічного захисту характерні для жінок, позитивно корелюють 3 захисними механізмами які $є$ типовими для фемінного гендеру (коефіцієнт кореляції склав Р>0,6). Це може говорить про те, що не залежно від гендерних особливостей, усім дівчатам властиве використання фемінних механізмів психологічного захисту, що демонструється на діаграмі (рис. 2.).

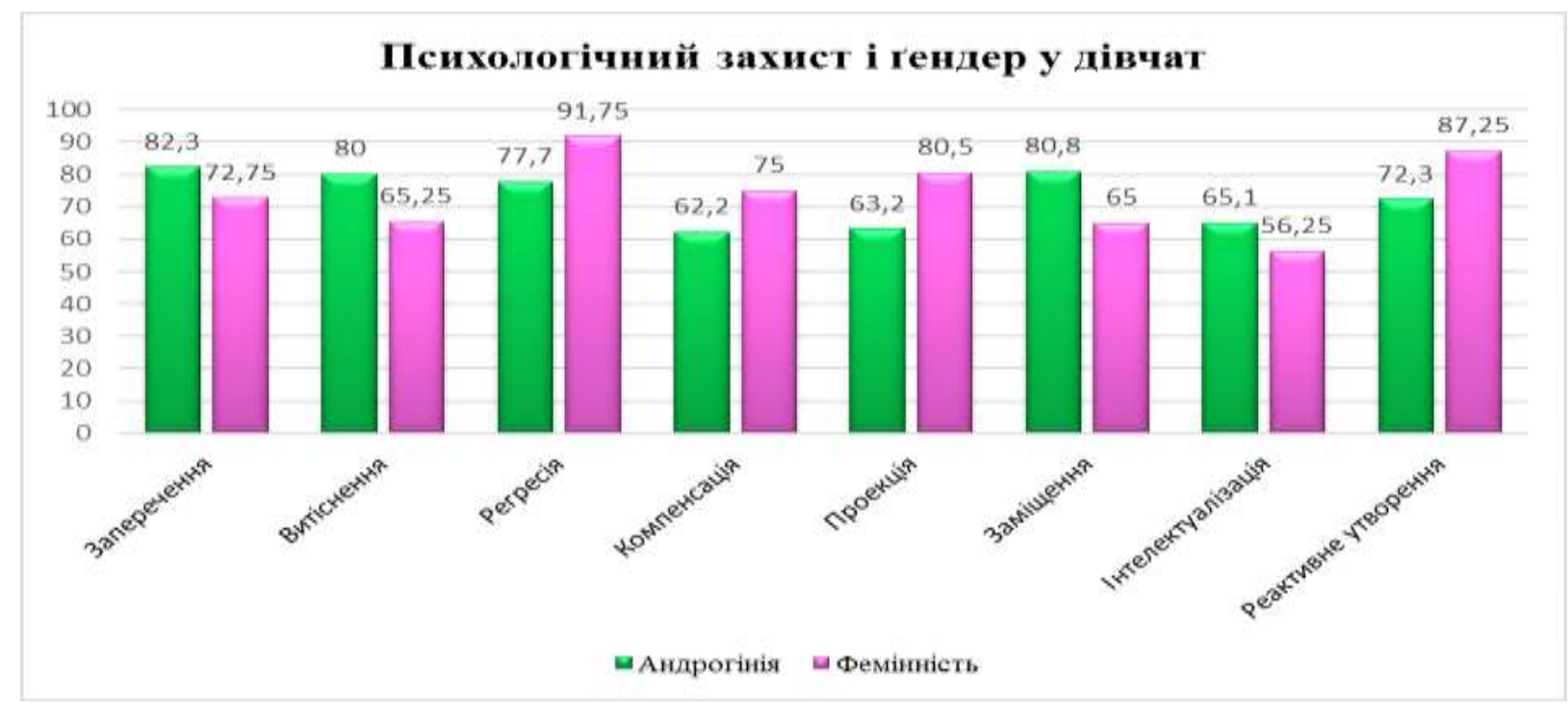

Рис. 2. Психологічний захист і гендер у дівчат

Але, у хлопців не спостерігається подібної тенденції, маскулінні механізми психологічного захисту мають незначну зворотну кореляцію і 3 власниками механізмів психологічного захисту, що типові для чоловіків і для жінок (коефіцієнт кореляції склав Р $<0,2$ ).

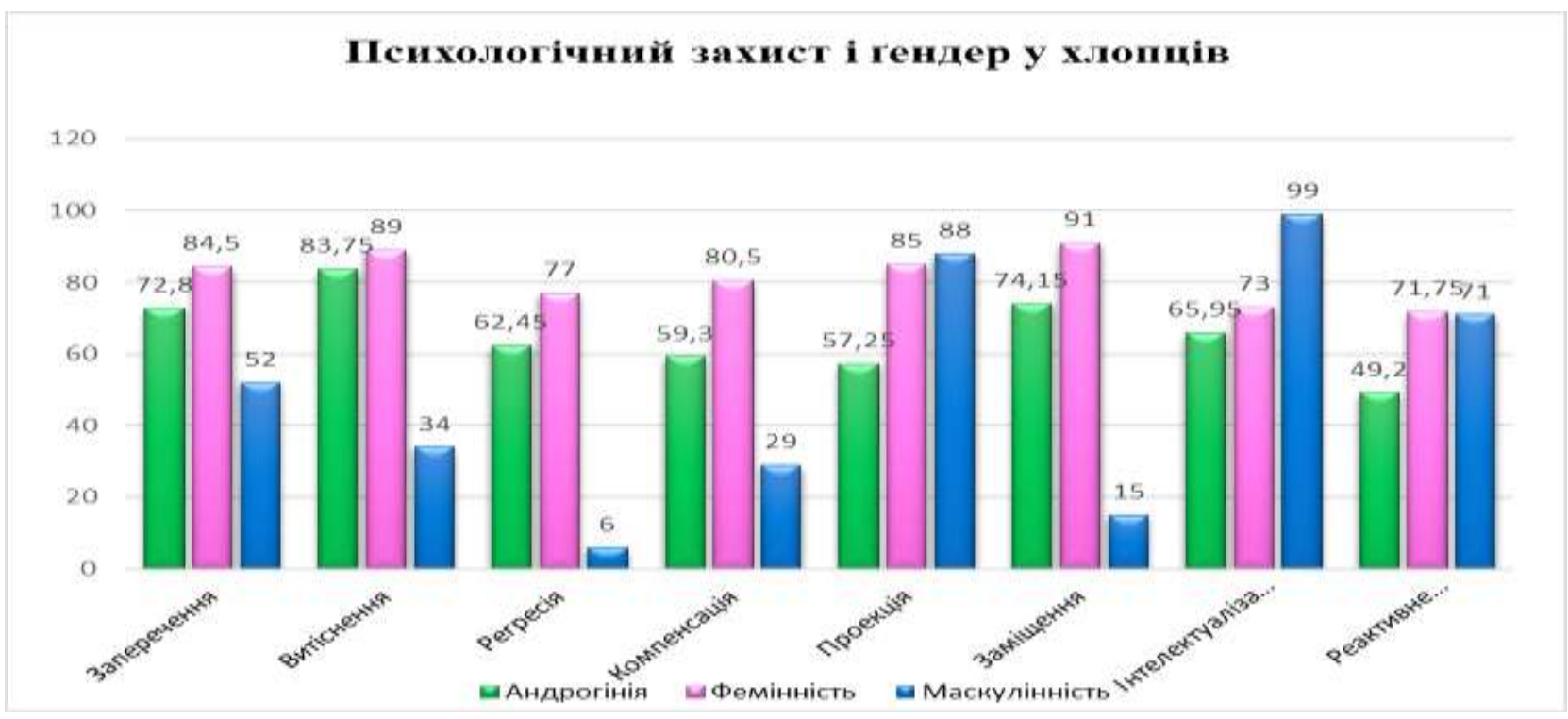

Рис. 3. Психологічних захист і гендер у хлопиів 
Отже можливо припустити, що механізми психологічного захисту більше залежать від гендеру (коефіцієнт кореляції склав Р>0,6), ніж від статі (коефіцієнт кореляції склав Р $>0,4)$. На нашу думку це пов'язано 3 тим, що на становлення статі впливають не тільки біологічні чинники, а і гендер, і механізми психологічного захисту формуються під впливом факторів зовнішньої середи.

Висновки. Таким чином, аналізуючи отримані данні, ми не можемо не звернути увагу на те, що механізми психологічного захисту, які $\epsilon$ типовими для чоловіків, позитивно корелюють з захисними механізмами, які властиві для фемінного гендеру (коефіцієнт кореляції склав $\mathrm{P}>0,7)$ (інтенсивність кореляції майже однакова 3 властивою дівчатам). Тобто особливості прояву механізмів психологічного захисту, які спостерігаються у власників фемінного гендеру з однаковою інтенсивністю проявляються як у хлопців, так і у дівчат. Це свідчить про те, що і жінки, і чоловіки фемінного гендеру використовують відносно однакові захисні механізми. Отже ми можемо припустити, що чоловіки, які на соціально-культурному, тобто гендерному рівні виказують більш жіночі риси особистості, безсвідомо, на що вказують механізми психологічного захисту, використовують умовно жіночі стратегії. У жінок ми не спостерігали подібної тенденції, але для більш ясних висновків дослідження потребує подальшої розробки і поширення вибірки.

\section{ЛІТЕРАТУРА}

1. Бэм С. Вопросник по изучению маскулинности - фемининности / Практикум по гендерной психологии Под ред. И.С.Клециной. СПб., 2003.- 280 с.

2. Берн Ш. Гендерная психология: Законы мужского и женского поведения. СПб., 2007.- С.41-45.

3. Гребенников Л.Р. Механизмы психологической защиты. Генезис. Функционирование. Диагностика. Под ред. Гребенникова Л.Р. - Мытищи: Талант, 2007. - 196 с.

4. Эриксон Э. Идентичность: юность и кризис / Э. Эриксон. - М. : Флинта, 2006. - 342 с.

5. Налчаджян А. А. Психологическая адаптация: механизмы и стратегии / А. А. Налчаджян. - М. : Эксмо, 2010. - 368 с.

6. Фрейд А. Психология Я и защитные механизмы. Пер. с англ. - М.: Проспект, 2009. - 256 с.

7. Фрейд 3. Введение в психоанализ : Лекции / 3. Фрейд. - СПб. : Лениздат, 2012. - 544 с.

8. Фрейд 3. Я иОно. По ту сторону принципа удовольствия. - М.: АСТ, 2011. - 288 с.

9. Хьелл Л. Зиглер Д. Теории личности. - 3-е изд. - СПб.: Питер, 2005. - 607 с.

10. Plutchik R. Emotions and psychotherapy: A psychoevolutionary perspective / R. Plutchik, H. Kellerman (Eds.). Emotion: Theory, research and experience. Vol. 5: Emotion, psychopathology and psychotherapy. San Diego., 1990. 